\title{
Long-Term Benefit of Bilateral Subthalamic Deep Brain Stimulation on Camptocormia in Parkinson's Disease
}

\author{
Bilateral Subtalamik Derin Beyin Stimülasyonunun Parkinson \\ Hastalığında Kamptokormi Üzerine Uzun Dönemli Etkisi
}

\author{
Mark LYONS ${ }^{1}$, Orland BOUCHER ${ }^{1}$, Naresh PATEL ${ }^{1}$, Barry BIRCH ${ }^{1}$, Virgilio EVIDENTE ${ }^{2}$ \\ ${ }_{1}^{1}$ Mayo Clinic Arizona, Department of Neurological Surgery, Phoenix/AZ, USA \\ ${ }_{2}^{2}$ Mayo Clinic Arizona, Department of Neurology, Phoenix/AZ, USA
}

Correspondence address: Mark LYONS / E-mail: lyons.mark2@mayo.edu

\begin{abstract}
We report the case of a 63-year-old female with a long history of severe Parkinson's disease (PD) and subsequent onset of debilitating camptocormia who underwent successful bilateral subthalamic nucleus deep brain stimulation surgery (STN DBS). The literature and previous reports are reviewed. The patient history and details of the surgical procedure are reported including the implantable pulse generator (IPG) settings and response to stimulation. The results of her PD symptom and camptocormia improvements are discussed. Five year postoperatively, the patient has enjoyed good results for both her PD symptoms as well as significant and sustained improvement in her thoracolumbar flexion deformity. She remains on minimal medications and no longer requires any assistive devices for ambulation. Comparison and contrast of the current world literature on DBS for camptocormia is reviewed. We discuss the current targets used for DBS in the setting of camptocormia in the cases reported, both PD associated and not associated. The optimal target has yet to be defined and further work on appropriate patient selection is needed.
\end{abstract}

KEYWORDS: Camptocormia, Deep brain stimulation, Globus pallidus internus, Parkinson's disease, Subthalamic nucleus

öz

Uzun süredir şiddetli Parkinson hastalığı $(\mathrm{PH})$ ve yakın zamanda maluliyete neden olan kamptokormisi olan ve bilateral subtalamik nükleus derin beyin stimülasyon cerrahisinin (STN DBS) başarıyla yapıldığı 63 yaşında bir kadın hastayı sunuyoruz. Literatür ve önceki raporlar gözden geçirilmektedir. Hasta öyküsü ve implante edilen puls jeneratörü (IPG) ayarları ve stimülasyona cevap dahil olmak üzere cerrahi işlem ayrıntıları bildirilmiş̧ir. PD belirtilerinin sonuçları ve kamptokormideki gelişmeler anlatılmaktadır. Ameliyattan beş yıl sonra hasta halen PD belirtileri açısından iyi sonuçlar ve torakolumbar fleksiyon deformitesinde önemli ve uzun süreli iyileşme mevcuttu. Hasta çok az sayıda ilaç kullanmakta ve artık ambulasyon için yardımcı cihazlara gereksinim duymamaktadır. Kamptokormi için DBS konusunda mevcut dünya literatürü bilgileri karşılaştırılmış ve değerlendirilmektedir. Bildirilen vakalarda PD ile ilişkili olsun veya olmasın kamptokormi durumunda DBS için kullanılan mevcut hedefleri gözden geçiriyoruz. Optimum hedefin halen tanımlanması gerekmektedir ve uygun hasta seçimi açısından hâlâ yapııması gerekenler vardır.

ANAHTAR SÖZCÜKLER: Kamptokormi, Derin beyin stimülasyonu, Globus pallidus internus, Parkinson hastalığı, Subtalamik nükleus

\section{INTRODUCTION}

Camptocormia is a disturbance of posture involving involuntary truncal flexion induced by standing or sitting. It is derived from the Greek words "to bend" and "trunk." It characteristically disappears in the recumbent position. Originally described by Brodil in 1837, the term camptocormia was introduced by Souques in 1915 when he reported on young French soldiers experiencing severe trunk flexion $(3,19,23,25)$. Treatment consisted of electrotherapy with immediate cure (24). Initially regarded as a psychiatric disorder, soldiers in World Wars I and II suffering from this disorder were often labeled as harboring a psychogenic illness $(1,2,5,10,19,21)$. At the time it was considered just another of the conversion reactions observed in many soldiers with difficulty adjusting to the stresses of combat. During World War I, of the 220 reported cases, 215 were soldiers primarily from the French and Italian armies (2). Even more recent reports have associated camptocormia with a conversion reaction disorder (18).

The majority of patients with camptocormia will exhibit kyphosis with flexion angles between 30 to 90 degrees. The differential diagnosis includes discogenic pain syndromes, vertebral infections or neoplasms, intraspinal hemorrhage, muscular dystrophies and psychological illnesses. Early treatment options were based upon the belief that the illness was essentially psychogenic hysterical reaction. Treatments included electrotherapy, backboards, therapeutic lumbar 
punctures, hypnosis and narcotherapy $(4,5,6,24,30)$. These early attempts at treatment were reported to result in sudden improvement and were designed to return the soldier to active duty as quickly as possible, however, very few treatments actually resulted in sustained relief.

More recently, camptocormia has been found to be associated with other neurological disorders, including idiopathic Parkinson's disease (PD) $(13,14,27,32)$. Medical treatments of the condition have generally been ineffective. We report on the current state of deep brain stimulation surgery in patients with idiopathic Parkinson's disease and concomitant camptocormia.

\section{CASE REPORT}

A 63-year-old woman with advanced PD and severe camptocormia was referred to our institution for evaluation and treatment. She presented with a several year history of motor fluctuations and dyskinesias, and severe forward and lateral camptocormia. This resulted in frequent falls of four to five per day. She was diagnosed with PD 19 years prior to presenting to our institution and the camptocormia started and progressed over the year. Multiple PD medications and analgesics had no effect on her camptocormia and associated back pain. She was taking carbidopa/levodopa 25/100 1 tablet 5x/day, pergolide $1 \mathrm{mg} 4 \mathrm{x} /$ day and amantadine 100 mg $2 x /$ day. She was dependent on most activities of daily living (ADLs) although required a walker for balance and because of her truncal flexion she could not see beyond her feet. Preoperatively, her Unified Parkinson's Disease Rating Scale (UPDRS) motor score was 35 off medication and 18 on medication. Pre-operatively, her camptocormia was characterized by an 80-90 degree flexion of her trunk in the thoracolumbar region along with a 20 degree left tilt. She had with moderate peak-dose disabling dyskinesias. The camptocormia was not relieved by her PD medications.

She underwent staged bilateral stereotactic-guided subthalamic nucleus deep brain stimulation (STN DBS) surgery (Medtronic ${ }^{\circledR}$ DBS lead model 3387S) with implantable

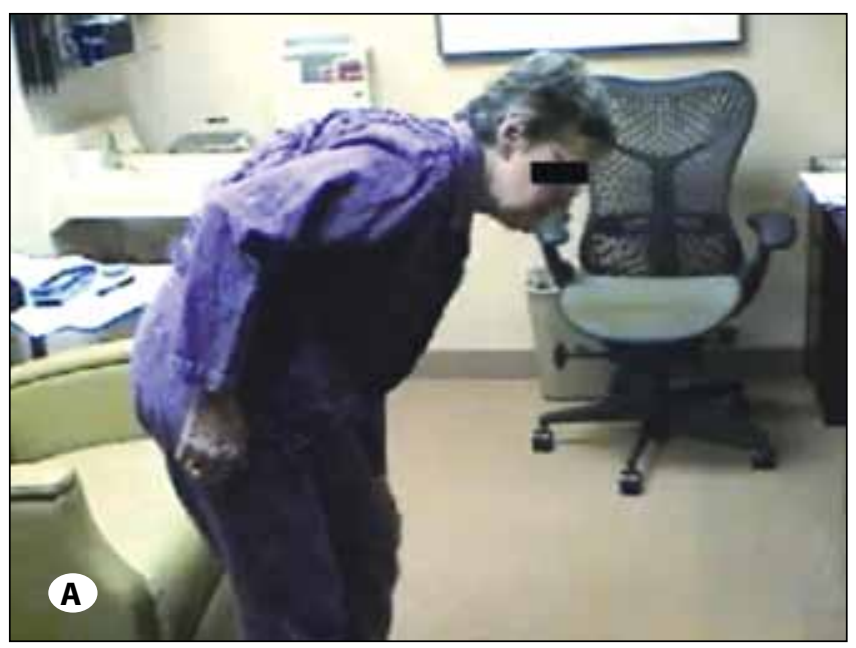

programmable pulse generator (IPG). The "midpoint" STN target was planned utilizing the coordinates $4 \mathrm{~mm}$ posterior, $5 \mathrm{~mm}$ inferior, and $12 \mathrm{~mm}$ lateral to the mid-commissural point. The Alpha-Omega Microguide system ${ }^{\circledast}$ was used for microelectrode nuclear mapping and microstimulation. Multiplanar post-operative cranial magnetic resonance imaging (MR) was performed to confirm accuracy of electrode placement in the STN. Her PD symptoms and camptocormia improved with initial programming 1 week postoperatively. Three months post-operatively programming parameters were: right IPG case $(+)$, electrodes $1 \& 3(-)$, amplitude $=2.4$ volts, pulse width $=90$ microseconds, rate $=185 \mathrm{~Hz}$; for the left IPG, settings were case (+), electrode $1(-)$, amplitude = 1.5 volts, pulse width $=120$ microseconds, rate $=185 \mathrm{~Hz}$. Her motor Unified Parkinson's Disease Rating Score (UPDRS) was 44 (medications off, stimulators off); 20 (medications off, stimulators on); and 15 (medications on, stimulators on). Her camptocormia had improved approximately $90 \%$ of her maximal flexion deformity, with a 10-20 degree truncal flexion on standing (Figure 1A, B). Her back pain also resolved postDBS. Beginning at 3 months postoperatively and continuing currently, she became independent for activities of daily living ( $A D L)$. She no longer needs a walker and has had no further falls. At five years post-DBS, her only PD medication is low dose carbidopa/levodopa 25/100 1 tablet bid. The STN stimulation continues to have a significant positive effect on her tremor, gait, balance and bradykinesia with no dyskinesias noted. Switching off of either one IPG or both IPGs results in dramatic worsening of her camptocormia.

\section{DISCUSSION}

Dystonia is a common characteristic in patients with severe PD presenting often with foot dystonia, blepharospasm and oromandibular dystonia $(11,26)$. Camptocormia may represent a form of dystonia in patients with PD, but this concept is not universally accepted $(11,22)$. Deep brain stimulation for patients with PD has been widely accepted as an alternative for these patients when medications are no longer effective or side effects are intolerable. There are a few

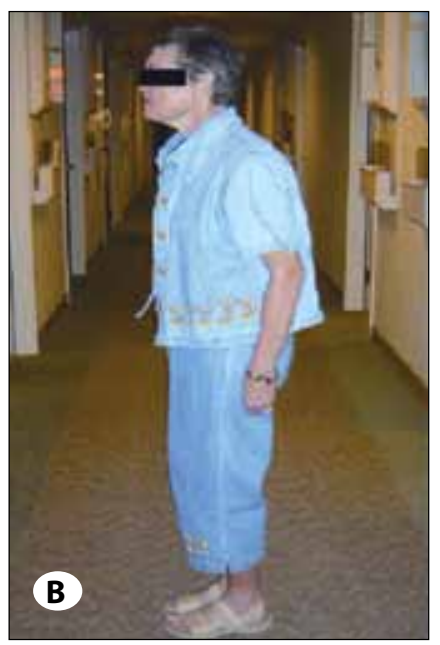

Figure 1: A) Patient before DBS surgery with severe camptocormia even in the medication on state. B) Patient at 3 months postDBS with significant relief of camptocormia after bilateral STN DBS with both stimulators on and no medications given. 
Table I: Deep Bain Stimulation Cases for Camptocormia

\begin{tabular}{|c|c|c|c|c|}
\hline Author & \# of Patients & PD & Target & Bilateral \\
\hline Nandi et al. 2002 & 1 & No & GPi & Yes \\
\hline Micheli et al. 2005 & 1 & Yes & GPi & Yes \\
\hline Sako et al. 2008 & 6 & Yes & STN & Yes \\
\hline Lyons et al. 2010 & 1 & Yes & STN & Yes \\
\hline
\end{tabular}

Abbreviations: PD, Parkinson's disease; GPi, globus pallidus internus; STN, subthalamic nucleus.

reports of cases of patients undergoing DBS surgery for PD who also have significant camptocormia $(11,20)$ (Table I). In addition, Nandi et al. reported a case of a young man without PD undergoing bilateral globus pallidus internus (GPi) DBS for disabling camptocormia secondary to neuroleptic medication side effects (13). The report by Slawek and colleagues was that of a 49-year-old woman with PD and camptocormia, who underwent unilateral pallidotomy that resulted in significant bilateral symptomatic improvement in her camptocormia (22). Micheli et al. targeted the globus pallidus internus bilaterally in their patient with PD and camptocormia also resulting in near complete resolution in the patient's truncal flexion deformity at 14 months postoperatively (11). Sako and colleagues, reporting on the largest series of PD patients with camptocormia undergoing DBS surgery, targeted the subthalamic nucleus (20). They reported on six patients undergoing bilateral STN DBS all of whom demonstrated significant improvement in their camptocormia as well as motor symptoms (20).

These reports, along with the observations in our patient, indicate that DBS surgery in PD patients with camptocormia can be expected to produce significant improvement in both conditions. Both the subthalamic nucleus and the globus pallidus internus have been successfully targeted in patients with severe camptocormia, with or without associated Parkinson's disease. Sako and colleagues noted significant postoperative improvement in the forward flexion angles, ranging from 67 to 89 percent (20). Of the 6 patients reported by Sako, the longest follow-up was less than 4 years. Our current case has had a 5 year follow-up period with continued response of her camptocormia to bilateral STN DBS. Micheli et al. did not report on specific percentage in flexion improvement following surgery, but noted that there was "almost no residual bending of the trunk." (11) The parkinsonian symptoms also improved markedly in the patients reported by Sako et al. and Micheli et al., as they did in our patient as well $(11,20)$. The report by Nandi was that of a patient who did not have Parkinson's disease also resulted in "significant functional improvement" as well as improvement in the patient's disabling neuropsychological scores (13).

The report by Djaldetti and co-workers initially described the association of camptocormia and Parkinson's disease as a dysfunction of the striatum causing an action dystonia (3). In addition, acute onset camptocormia was reported associated with lenticular lesions and the possible role of the striatum and pallidum in maintaining axial posture (14). With the well-documented success of pallidotomy and GPi DBS for dystonia, the GPi makes an attractive target for patients with camptocormia $(9,28,29)$. The success of STN DBS in patients with Parkinson's disease has been extensively reported $(8,12,16)$. The improvement in the motor fluctuations and the resultant decrease in dopaminergic medications may be superior with STN versus GPi DBS but recent results suggest that equivalent improvements can be made with either target (17). In terms of effects on cognition and mood in PD patients, unilateral STN DBS and unilateral GPi DBS have equivalent effects post-operatively (15). However, in the elderly population, less cognitive impairment in severe PD patients undergoing bilateral GPi versus STN DBS has been noted (Evidente, unpublished data). The recent findings that STN DBS can be effective for primary and secondary dystonias helps expand the potential targets for treatment of the underlying parkinsonian features, as well as the camptocormia, with consideration of the patient's baseline neuropsychological status $(7,15,30,31)$. Reports of success in controlling the axial posturing in patients with camptocormia with both STN and GPi stimulation support the notion that the basal ganglia plays an important role in maintenance of posture.

\section{CONCLUSIONS}

Our current case represents the longest follow-up period of continued benefit of PD-related camptocormia to bilateral STN DBS. Our patient's sustained response to bilateral STN DBS for both her PD symptoms and her camptocormia are consistent with previous reports $(11,13,20)$. Additional cases with longer follow-up periods are needed to confirm the findings thus far reported. The optimal target and appropriate patient selection remain to be defined, though all reports seem to indicate that bilateral stimulation benefits camptocormia in PD patients.

\section{REFERENCES}

1. Ballenger JC: $A$ case of camptocormia occurring in psychotherapy. J Nerv Ment Dis 162:291-294, 1976

2. Divry P: Camptocormia post-traumique. Liege Med 22: 585-590, 1929

3. Djaldetti R, Mosberg-Galili R, Sroka H, Merims D, Melamed E: Camptocormia (bent spine) in patients with Parkinson's Disease-Characterization and possible pathogenesis of an unusual phenomenon. Mov Disorders 14:443-447, 1999

4. Fetterman JL: Back disorders of psychic origin. Ohio State Med J 33:777-781, 1937 
5. Hurst AF: The bent back of soldiers. Br Med J 2:621-624, 1918

6. Karbowski K: The old and new camptocormia. Spine 24: 1494-1498, 1999

7. Kleiner-Fisman G, Liang GS, Moberg PJ, Ruocco AC, Hurtig HI, Baltuch GH, Jaggi JL, Stern MB: Subthalamic nucleus deep brain stimulation for severe idiopathic dystonia: Impact on severity, neuropsychological status, and quality of life. J Neurosurg 107(1):29-36, 2007

8. Krack $P$, Batir A, van Blercom N, Chabardes S, Fraix V, Ardoiun C, Koudsie A, Limousin PD, Benazzouz A, LeBas JF, Benabid $\mathrm{AL}$, Pollak P: Five-year follow-up of bilateral stimulation of the subthalamic nucleus in advanced Parkinson's disease. $\mathrm{N}$ Engl J Med 349:1925-1934, 2003

9. Krauss JK: Brain stimulation for dystonia in adults. Overview and developments. Stereotact Funct Neurosurg 78:168-182, 2002

10. Massa $E$, Slater CB: Camptocormia and depression: A case report. Mil Med 154:352-355, 1989

11. Micheli F, Cersosimo MG, Piedimonte F: Camptocormia in a patient with Parkinson's disease: beneficial effects of pallidal deep brain stimulation. Case report. J Neurosurg 103: 1081-1083, 2005

12. Moro E, Scerrati M, Romito LM, Roselli R, Tonali P, Albanese A: Chronic subthalamic nucleus stimulation reduces medication requirements in Parkinson's disease. Neurology 53:85-90, 1999

13. Nandi D, Parkin S, Scott R, Winter JL, Joint C, Gregory R, Stein J, Aziz TZ: Camptocormia treated with bilateral pallidal stimulation. Case report. Neurosurg Focus 12:1-6, 2002

14. Nieves AV, Miyasaki JM, Lang AE: Acute onset dystonic camptocormia caused by lenticular lesions. Mov Disord 16:177-180, 2001

15. Okun MS, Fernandez HH, Wu SS, Kirsch-Darrow L, Bowers D, Bova F, Suelter M, Jacobson CE $4^{\text {th }}$, Wang X, Gordon CW Jr, Zeilman P, Romrell J, Martin P, Ward H, Rodriguez RL, Foote KD: Cognition and mood in Parkinson's disease in subthalamic nucleus versus globus pallidus interna deep brain stimulation: The COMPARE trial. Ann Neurol 65:586-595, 2009

16. Pastor-Gomez J, Hemando-Requejo V, Luvengo-Dos Santos A, Pedrosa-Sanchez M, Sola RG: Treatment of a case of generalized dystonia using subthalamic stimulation. Rev Neurol 37:529-531, 2003

17. Premkumar $A$, Lyons $M K$, Hillman $R$, Falk $B$, Lemens $S M$, Wheeler MA, Caviness JN, Driver-Dunckley E, Adler CA, Evidente VGE: Post-operative medication doses are reduced equally in Parkinson's patients who undergo either bilateral pallidal or subthalamic deep-brain stimulation. J Neurol 255(Suppl 2):98-99, 2008
18. Rajmohan V, Thomas B, Sreekumar K: Case study: Camptocormia, a rare conversion disorder. J Am Acad Child Adolesc Psychiatry 43:1168-1170, 2004

19. Rosen JC, Frymoyer JW: A review of camptocormia and an unusual case in the female. Spine 10(4):325-327, 1985

20. Sako W, Nishio M, Maruo T, Shimazu H, Matsuzaki K, Tamura T, Mure H, Ushio Y, Nagahiro S, Kaji R, Goto S: Subthalamic nucleus deep brain stimulation for camptocormia associated with Parkinson's disease. Mov Disorders 24(7):1076-1079, 2009

21. Sandler SA: Camptocormia: A functional condition of the back in neurotic soldiers. War Med 8:36-45, 1945

22. Slawek J, Derejko M, Lass P: Camptocormia as a form of dystonia in Parkinson's disease. Eur J Neurol 10:107-108, 2003

23. Souques A: Reformes, incapacities, gratifications dans la camptocormie. Rev Neurol 223:757-758, 1916

24. Souques A:Traitement de la camptocormie par l'electrotherapie persuasive. Rev Neurol 24:345-446, 1917

25. Souques A, Rosanoff-Saloff: La camptocormie: Incurvation du tronc. Rev Neurol 22:937-939, 1915

26. Sun B, Chen S, Zhan S, Le W, Krahl SE: Subthalamic nucleus stimulation for primary dystonia and tardive dystonia. Acta Neurochir 97:207-214, 2007

27. Van Gerpen JA: Camptocormia secondary to early amyotrophic lateral sclerosis. Mov Disorders 16:358-360, 2001

28. Vidailhet $M$, Vercueil L, Houeto JL, Krystkowiak P, Lagarnge $C$, Yelnik J, Bardinet E, Benabid AM, Navarro S, Vormont D, Grand S, Blond S, Ardouin C, Pillon B, Dujardin K, Hahn-Barma V, Agid Y, Destee A, Pollak P, The French SPIDY Study Group: Bilateral deep-brain stimulation of the globus pallidus in primary generalized dystonia. Lancet 6:223-229, 2007

29. Vitek JL, Chockkan V, Zhang JY, Kaneoke Y, Evatt M, DeLong MR, Triche S, Mewes K, Hashimoto T, Bakay RA: Neuronal activity in the basal ganglia in patients with generalized dystonia and hemiballismus. Ann Neurol 46(1):22-35, 1999

30. Weiss II: A study of camptocormia with presentation of three postspinal cases. Mil Surg 97:462-474, 1945

31. Zhang J-G, Zhang K, Wang Z-C, Ge M, Ma Y: Deep brain stimulation in the treatment of secondary dystonia. Chin Med J 119:2069-2074, 2006

32. Zwecker M, lancu I, Zelig G, Ohry A: Camptocormia: A case of possible paraneoplastic etiology. Clin Rehab 12:157-160, 1998 